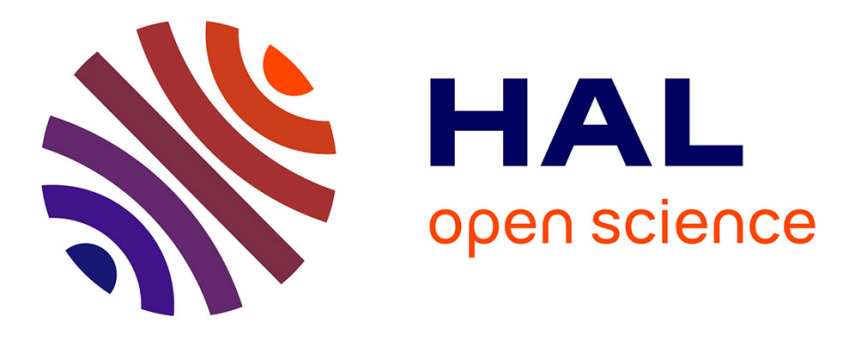

\title{
Bioaccumulation of 12 trace elements in the tissues of the nautilus Nautilus macromphalus from New Caledonia
}

Paco Bustamante, Sveva Grigioni, Renata Boucher-Rodoni, Florence Caurant, Pierre Miramand

\section{To cite this version:}

Paco Bustamante, Sveva Grigioni, Renata Boucher-Rodoni, Florence Caurant, Pierre Miramand. Bioaccumulation of 12 trace elements in the tissues of the nautilus Nautilus macromphalus from New Caledonia. Marine Pollution Bulletin, 2000, 40 (8), pp.688-696. 10.1016/S0025-326X(00)00005-9 . hal-00186630

\section{HAL Id: hal-00186630 \\ https://hal.science/hal-00186630}

Submitted on 10 Nov 2007

HAL is a multi-disciplinary open access archive for the deposit and dissemination of scientific research documents, whether they are published or not. The documents may come from teaching and research institutions in France or abroad, or from public or private research centers.
L'archive ouverte pluridisciplinaire HAL, est destinée au dépôt et à la diffusion de documents scientifiques de niveau recherche, publiés ou non, émanant des établissements d'enseignement et de recherche français ou étrangers, des laboratoires publics ou privés. 


\title{
Bioaccumulation of 12 trace elements in the tissues of the nautilus Nautilus macromphalus from New-Caledonia
}

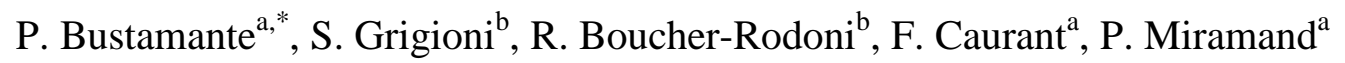

${ }^{\text {a }}$ Laboratoire de Biologie et d'Environnement Marins, Université de La Rochelle, Avenue Marillac, 17042 La Rochelle Cedex, France

*Corresponding author.Tel./Fax: +33 546-513-942 ; e-mail: paco.bustamante@univ-lr.fr

${ }^{\mathrm{b}}$ Laboratoire de Biologie des Invertébrés Marins et Malacologie, URA CNRS 699, Muséum National d'Histoire Naturelle, 57 rue Cuvier 75231 Paris Cedex 03

\begin{abstract}
Soils in New Caledonia are particularly rich in metals among which Fe and $\mathrm{Ni}$ are intensively exploited. Due to important natural erosion in tropical latitudes and to mining activities, coastal waters are enriched in $\mathrm{Co}, \mathrm{Cr}, \mathrm{Fe}$ and $\mathrm{Ni}$. In deeper waters lives a cephalopod species which is considered as a living fossil, the nautilus Nautilus macromphalus. In this study, 12 traces elements were analysed in the tissues of 4 nautilus specimens. Results showed high metal concentrations compared to data available for cephalopod from temperate waters. These concentrations were often in the same order than those encountered in bivalves or gastropods from contaminated areas. Relatively high concentrations of $\mathrm{Ni}$ and $\mathrm{Cr}$ in the hemolymph strongly suggest a high exposure of $N$. macromphalus to these metals. Among the tissues, the digestive gland have the highest concentrations of $\mathrm{Cd}, \mathrm{Co}, \mathrm{Fe}, \mathrm{V}$ and $\mathrm{Zn}$ while for $\mathrm{Ag}, \mathrm{Al}, \mathrm{As}, \mathrm{Cr}$ and $\mathrm{Ni}$, renal and pericardial appendages exhibited the highest values. Despite this, the digestive gland contained the largest quantities of all metals with the exception of As and Mn which were mainly found in the body
\end{abstract}


muscular remains. These results highlighted the major role of digestive gland and excreting organs in the metabolism of metals in these cephalopod species.

Keywords: New Caledonia ; trace metals ; cephalopods ; digestive gland ; nautilus

\section{Introduction}

Cephalopods play a key role in many marine ecosystems (Amaratunga 1983, Rodhouse 1989). Trace elements have been investigated extensively in many marine organisms but rarely in cephalopods. Some elements are essential, others toxic, and for a number of them the role is still not known. The studies concerning trace elements in cephalopods molluscs are limited to species targeted by commercial fisheries such as the cuttlefish Sepia officinalis (Decleir et al. 1978, Schipp \& Hevert 1978, Miramand \& Bentley 1992, Bustamante 1998), the octopuses Octopus vulgaris and Eledone cirrhosa (Ghiretti-Magaldi et al. 1958, Rocca 1969, Renzoni et al. 1973, Froesch \& Packard 1979, Ueda et al. 1979, Miramand \& Guary 1980, Miramand \& Bentley 1992, Barghigiani et al. 1993, Rossi et al. 1993, Bustamante 1998), some Ommastrephid squids (Martin \& Flegal 1975, Ueda et al. 1979, Smith 1983, Smith et al. 1984, Finger \& Smith 1987, Yamada et al. 1997, Bustamante 1998) and some Loliginid squids (Martin \& Flegal 1975, Yamada et al. 1997, Bustamante 1998). Among these species, high levels of metals have generally been recorded, the digestive gland of Coleidae concentrating many trace elements, such as cadmium, copper, silver or zinc (Martin \& Flegal 1975, Smith et al. 1984, Miramand \& Guary 1980, Finger \& Smith 1987, Miramand \& Bentley 1992, Bustamante 1998, Bustamante et al 1998a). The most striking feature is that the digestive gland stores most of the total cadmium, reaching up $98 \%$ in some species (Bustamante 1998). 
Present cephalopods comprise two subclasses: the Coleoidae, with ca 650 species and the Nautiloidae with a single genus (Nautilus) and an as yet undetermined number of species (3 to 7 according to the authors). Nautilus is the last representative of the ectocochleate cephalopods and is considered as a living fossil. This taxon shares a number of common anatomical structures with present cephalopods, but some organs are specific to Nautilus.

Among the nautilus species, Nautilus macromphalus is endemic to the New Caledonian waters. In this area, natural erosion and mining activity have provoked an enrichment of several metals, mainly $\mathrm{Co}, \mathrm{Cr}, \mathrm{Fe}$ and $\mathrm{Ni}$, of the New Caledonian waters and consequently in the coral reef food webs (Monniot et al. 1994). These authors have described the metal enrichment in several species of filter-feeding ascidians from the shallow waters. But no data are available on species living off the New Caledonia coast.

For these reasons, levels of trace elements in the tissues of Nautilus macromphalus from New Caledonia were investigated here and compared to previous results reported for Coleoid species.

\section{Materials \& Methods}

Sampling and sample preparation

2 males and 2 females Nautilus macromphalus were taken in baited traps from the barrier reef off Nouméa (New Caledonia). Samples were frozen upon arrival at the Nouméa Aquarium in individual plastic bags. Each individual was weighed and sexed. The digestive gland, gills, renal and pericardial appendages, digestive tract and genital tract were totally removed. In addition, pieces of muscle and crop were sampled to determine metal concentrations. The remains of the animals were thus composed of arms, the rest of the muscles and the rest of the crop. The stomach was emptied before metal analysis. 


\section{Analytical procedure}

Tissue samples were dried for several days at $80^{\circ} \mathrm{C}$ to constant weight. Two aliquots of approx. $300 \mathrm{mg}$ of each homogenised dry sample were digested with $4 \mathrm{ml}$ of $65 \% \mathrm{HNO}_{3}$ and $1 \mathrm{ml}$ of $70 \% \mathrm{HClO}_{4}$ at $80^{\circ} \mathrm{C}$ until the solution was clear. After evaporation, the residues were dissolved in $0.3 \mathrm{~N}$ nitric acid.

Cadmium, Copper and Zinc were determined both by atomic absorption spectrophotometry (AAS) and by induced coupled plasma mass spectrophotometry (ICP-MS). Other elements (Ag, As, Al, Co, Cr, Fe, Mn, Ni and V) were analysed only by ICP-MS.

Appliances used for metals determination were a Varian spectrophotometer Vectra 250 Plus with Deuterium background correction and a Varian ICP-MS Ultra Mass 700. Reference tissues, dogfish liver DOLT-2 (NRCC), Orchard-Leaves (NBS) and MA-A-2 fish-flesh standard (IAEA), were treated and analysed in the same way as the samples. The results for the standard reference materials (Table 1) are in good agreement with certified values. The detection limits were ( $\mu \mathrm{g} / \mathrm{g}$ dry wt): $0.002(\mathrm{Ag}), 0.005$ (Al), 0.15 (As), 0.005 (Cd), 0.005 (Co), $0.005(\mathrm{Cr}), 0.027(\mathrm{Cu}), 0.15(\mathrm{Fe}), 0.017(\mathrm{Mn}), 0.002(\mathrm{Ni}), 0.005(\mathrm{~V})$ and $0.15(\mathrm{Zn})$. Metal concentrations in tissues are given relatively to the dry weight $\left(\mu \mathrm{g} \cdot \mathrm{g}^{-1}\right.$ dry wt) while the distribution percentages were calculated for wet weight.

\section{Results}

Metal concentration in the organs of nautilus are reported in Figure 1. The percentage of heavy metals in each tissue are shown in Figure 2. 


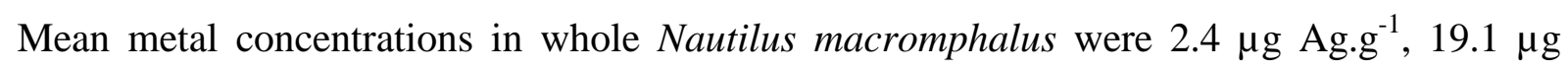
Al.g ${ }^{-1}, 186 \mu \mathrm{g}$ As.g ${ }^{-1}, 16.0 \mu \mathrm{g} \mathrm{Cd.g}{ }^{-1}, 2.7 \mu \mathrm{g} \mathrm{Co.g}^{-1}, 2.6 \mu \mathrm{g} \mathrm{Cr.g}{ }^{-1}, 73 \mu \mathrm{g} \mathrm{Cu.g}{ }^{-1}, 258 \mu \mathrm{g} \mathrm{Fe.g}{ }^{-1}$,

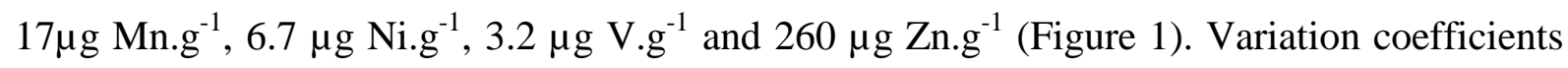
ranged from $10 \%$ for As to $45 \%$ for Co and Ni.

Metal levels in soft tissues

In the four sampled nautilus, the digestive gland was the major site of concentration for $\mathrm{Cd}$,

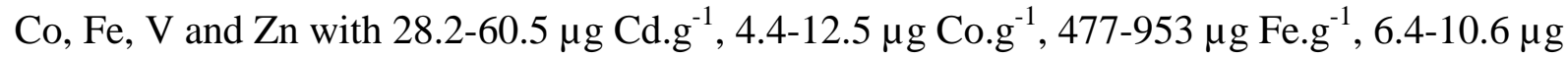
V.g ${ }^{-1}$ and 515-963 $\mu \mathrm{g} \mathrm{Zn.g}{ }^{-1}$ (Figure 1). The digestive gland also concentrated Ag, As, Cr, Cu and $\mathrm{Ni}$ at levels closed to the highest concentrations recorded in the other tissues with 1.1-6.8

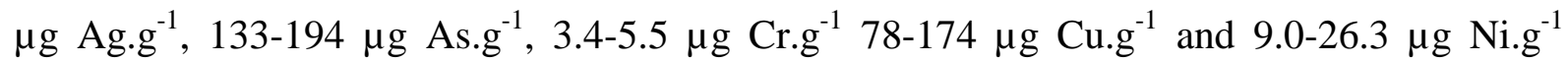
(Figure 1).

$\mathrm{Ag}, \mathrm{Al}, \mathrm{As}, \mathrm{Cr}$ and $\mathrm{Ni}$ concentrations were also remarkable in excreting tissues, i.e. renal and pericardial appendages, which exhibited the highest concentrations for these metals. In fact, $\mathrm{Ni}$ concentrations ranged from 5.6 to $40.0 \mu \mathrm{g} . \mathrm{g}^{-1}$ in renal appendages. Pericardial appendages concentrated Ag from 13.8 to $28.0 \mu \mathrm{g} \cdot \mathrm{g}^{-1}$, Al from 45 to $305 \mu \mathrm{g} \cdot \mathrm{g}^{-1}$, As from 155 to $412 \mu \mathrm{g} . \mathrm{g}^{-1}$ and $\mathrm{Cr}$ from 6.0 to $9.4 \mu \mathrm{g} \cdot \mathrm{g}^{-1}$ (Figure 1).

Muscles exhibited generally the lowest concentration for all metals except for As which

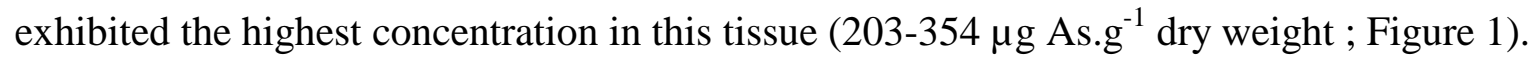

Mn was present in high concentration in the gills and the renal appendages (i.e. $42-151 \mu \mathrm{g} . \mathrm{g}^{-1}$ and 16-152 $\mu \mathrm{g} \cdot \mathrm{g}^{-1}$, respectively) while most tissues exhibited concentrations lower than 20 $\mu \mathrm{g} \cdot \mathrm{g}^{-1}$. The highest $\mathrm{Cu}$ concentration was found in the hemolymph, with mean values of 1055 $\pm 12 \mu \mathrm{g} \cdot \mathrm{g}^{-1}$. Thus, it is not surprising to find relatively high $\mathrm{Cu}$ concentrations in the gills (i.e. $\left.127 \pm 38 \mu \mathrm{g} \cdot \mathrm{g}^{-1}\right)$. 
With the exception of As and Mn which were mainly found in the body muscular remains (50 $\pm 12 \%$ and $42 \pm 16 \%$, respectively), the digestive gland contained the largest quantities of all metals : $75 \pm 3 \%$ of $\mathrm{Ag}, 62 \pm 11 \%$ of $\mathrm{Al}, 96 \pm 3 \%$ of $\mathrm{Cd}, 95 \pm 2 \%$ of $\mathrm{Co}, 57 \pm 16 \%$ of $\mathrm{Cu}, 65$ $\pm 5 \%$ of $\mathrm{Cr}, 87 \pm 4 \%$ of $\mathrm{Fe}, 84 \pm 8$ of Ni, $95 \pm 3 \%$ of $\mathrm{V}$ and $88 \pm 3 \%$ of $\mathrm{Zn}$ (Figure 2 ).

Although the concentration of some metals was high in the renal and pericardial appendages, these tissues contain in fact low amounts of metals because of their small mass (Figure 2).

\section{Discussion}

The variability of metal concentration was relatively small among the four studied individuals. Low variation coefficients for toxic metals such as $\mathrm{Ag}, \mathrm{Cd}$ or $\mathrm{V}(26 \%, 41 \%$ and $34 \%$, respectively) are noteworthy. Nevertheless, coefficients of variation for $\mathrm{Cd}$ are similar to those found in two octopus species from the Southern Indian Ocean, Benthoctopus thielei and Graneledone, reported to have very high Cd levels in their tissues (Bustamante et al. 1998a). Such results suggest efficient regulation processes of toxic metals in Nautilidae even Cd levels were lower in Nautilus macromphalus than in these octopuses. Some other toxic elements, $\mathrm{Ag}, \mathrm{Co}, \mathrm{Cr}, \mathrm{Ni}$ and $\mathrm{V}$, were more concentrated in nautilus than in temperate cephalopods such as the cuttlefish Sepia officinalis and the octopuses Eledone cirrhosa and Octopus vulgaris (Miramand \& Guary 1980, Miramand \& Bentley 1992). This might be due to accumulation during nautilus life span (10-15 years), much longer than Coleoid's (1-3 years). Moreover, several essential metals, such as $\mathrm{Fe}, \mathrm{Mn}$ and $\mathrm{Zn}$ were also highly concentrated in $N$. macromphalus, but $\mathrm{Cu}$ concentrations almost the same as in Coleoidae species (Miramand \& Guary 1980, Miramand \& Bentley 1992, Bustamante et al. 1998a). High metal concentrations 
might reflect the ambient life conditions of nautilus. Mineral extraction activity, mainly Ni, is important in New Caledonia : Ni enrichment in the waters and food webs might thus account for high levels of Ni in N. macromphalus. Although the dissolved Ni have not been measured, large amounts in coastal sediments suggests that abnormal concentration may occur in sea water (Bryan 1976, Monniot et al. 1994). Indeed, Monniot et al. (1994) reported very high Ni concentrations in the body and the tunic of Ascidia sydneiensis from coastal waters, reaching 80.4 and $119.5 \mu \mathrm{g} / \mathrm{g}$ dry wt, respectively. Compared to other molluscs species, $\mathrm{Ni}$ concentrations in $N$. macromphalus were in the same order of magnitude than in several deposit feeder species such as Scrobicularia plana or Macoma balthica but are higher than in filter feeder species such as Pecten maximus or Mytilus edulis (Table 2). It was also the case for $\mathrm{Co}$ and $\mathrm{Cr}$. High levels of $\mathrm{Ni}, \mathrm{Co}$ and $\mathrm{Cr}$ in deposit feeder bivalves were related to direct exposure through contaminated sediments (Bryan \& Hummerstone 1977). This strongly suggest that contamination is not only located on the New Caledonian coast but reach deeper waters where nautilus lives. This hypothesis is reinforced by the relatively high concentrations for these metals encountered in the hemolymph. Indeed, in circulatory fluid as hemolymph, turnover of metals is supposed to be rapid and by the way, metal concentrations relatively low, with the exception of $\mathrm{Cu}$ which is a main component of hemocyanin. It is the case for most of the trace elements analysed but not for $\mathrm{Ni}$ and $\mathrm{Cr}$ (Figure 1). This supposed a high exposure of nautilus to these metals.

Concerning Fe, N. macromphalus exhibit higher concentrations than in cephalopods from temperate waters that could also indicated contamination (Table 2). Nevertheless, Fe concentrations are lower than in bivalve and gastropod species from contaminated areas and were relatively low in hemolymph (Table 2). 
Table 3 compares the trace element concentrations in the digestive gland of Nautilus macromphalus with those reported for other cephalopod species. The relative weight of the digestive gland in our samples is higher than in most of Coleoidae species. Indeed, the digestive gland consists of $20 \pm 5 \%$ of the fresh weight of the soft tissues of $N$. macromphalus while in Coleoidae, it represent 6 to $10 \%$ of the total body weight. Thus, when metals were highly concentrated in the digestive gland (e.g. Cd), metal concentrations in the whole individuals were proportionally higher than in other cephalopod species.

$\mathrm{Ag}, \mathrm{Cd}, \mathrm{Co}, \mathrm{Cr}, \mathrm{Ni}$ and $\mathrm{V}$ levels in the digestive gland of $N$. macromphalus are higher than those reported for Eledone cirrhosa and Sepia officinalis from the English Channel. Nevertheless, several squid species, i.e. Loligo opalescens, Ommastrephes bartrami and Sthenoteuthis oualaniensis from the Pacific Ocean, exhibit higher concentrations of Ag in their digestive gland (Martin \& Flegal 1975). These authors explain these very high Ag concentrations by the release of the metal in the Californian waters. This suppose very high ability of cephalopods to concentrate $\mathrm{Ag}$. For $\mathrm{Cd}$, these squids and the octopuses from Kerguelen Islands (i.e. Graneledone sp. and Benthoctopus thielei) have far higher concentrations in the digestive gland than nautilus (Bustamante et al. 1998a). Although Cd concentrations in $N$. macromphalus were higher than in squids and cuttlefish from temperate waters (Table 3, Bustamante et al. 1998b), it doesn't indicate a contamination as they are in the same order of magnitude than in octopus species from these areas. Concentrations of $\mathrm{Cu}$, $\mathrm{Fe}, \mathrm{Mn}$ and $\mathrm{Zn}$ in the digestive gland of $N$. macromphalus, all essential elements, are in the same order of magnitude as those of other cephalopod species. Thus, these elements are properly regulated in the digestive gland of $N$. macromphalus as in the other cephalopod species. Results for As appear to be the first reported for the cephalopod digestive gland. For Al, concentrations can only be compared with those in the squid Nototodarus gouldi (Smith et al. 1984) which are ranged from 1.5 to $20 \mu \mathrm{g} / \mathrm{g}$ (Table 3). 
Globally, concentrations of the toxic elements in the digestive gland of Nautilus macromphalus are generally higher than those reported for cephalopods from the French coasts, i.e. Sepia officinalis, Eledone cirrhosa and Octopus vulgaris (Table 3).

In the Coleoidae species, branchial hearts have been reported to concentrate essential elements such as Fe and Cu (Fox \& Updegraff 1943, Ghiretti-Magaldi et al. 1958, Nardi \& Steinberg 1974, Schipp \& Hevert 1978, Miramand \& Bentley 1992). These organs also concentrate toxic and radioactive elements such as ${ }^{241} \mathrm{Am}, \mathrm{Co}, \mathrm{Ni},{ }^{239-240} \mathrm{Pu}$ and $\mathrm{V}$ (Ueda et al. 1979, Nakahara et al. 1979, Miramand \& Guary 1980, Guary et al. 1981, Guary \& Fowler 1982, Miramand \& Bentley 1992). Moreover, kidneys of cephalopods have been shown to store $\mathrm{Cd}, \mathrm{Cu}, \mathrm{Fe}, \mathrm{Mn}, \mathrm{Ni}$ and $\mathrm{Pb}$ (Miramand \& Guary 1980, Miramand \& Bentley 1992).

High concentrations of trace elements ( $\mathrm{Ag}, \mathrm{Al}, \mathrm{As}, \mathrm{Cr}, \mathrm{Fe}, \mathrm{Ni}$ and $\mathrm{Mn}$ ) were found in organs concerned with excretion, i.e. the pericardial and renal appendages (Figure 1). These results, and those concerning the digestive gland, suggest that these metals could follow another way of detoxification in nautilus than in the few Coleoidae species studied. The digestive gland would assume mainly the detoxification of metals such as $\mathrm{Cd}, \mathrm{V}$ or $\mathrm{Zn}$. The hypothesis is strengthened by the trace element levels in the circulatory fluid. Indeed, as the food can be considered as the main source of metals in cephalopods since they are carnivorous, the hemolymph would be a major vector for metal distribution among the different tissues. Metal levels in the hemolymph of Nautilus macromphalus showed relatively low concentrations for most elements, except for $\mathrm{Cu}$ which is present in hemocyanin. This is particularly clear for $\mathrm{Cd}, \mathrm{V}$ and $\mathrm{Zn}$ which exhibited the lowest concentrations in the hemolymph (Figure 1).

The other tissues store trace element in much lower amounts than the digestive gland, the renal and the pericardial appendages. Nevertheless, muscles which generally exhibit the 
lowest metal concentrations, showed the highest As concentrations. This could be due to high consumption of crustaceans which are particularly rich in As.

Investigations on trace element concentrations in the tissues have highlighted the key role of the digestive gland of nautilus in the metabolism of metals, as is also the case in Coleoidae. This organ is indeed the major site of concentration of $\mathrm{Cd}, \mathrm{Co}, \mathrm{Fe}, \mathrm{V}$ and $\mathrm{Zn}$ and, compared to other tissues, it shows also high levels of $\mathrm{Ag}, \mathrm{As}, \mathrm{Cr}, \mathrm{Cu}$ and $\mathrm{Ni}$ (Figure 1). The digestive gland contains the highest percentage of metals, with the exception of As and Mn (Figure 2). Miramand \& Bentley (1992) have classified some trace elements based on the ratio between the concentration in the digestive gland and in the muscle. Thus, in the digestive gland, three groups of elements can be evidenced in Nautilus macromphalus : poorly concentrated elements, i.e. $\mathrm{Al}, \mathrm{As}, \mathrm{Cr}, \mathrm{Cu}$ and $\mathrm{Mn}$ (ratio <10), moderately concentrated elements, i.e. Fe, $\mathrm{Ni}$ and $\mathrm{Zn}$ (ratio >10 to <50) and highly concentrated elements, i.e. $\mathrm{Ag}, \mathrm{Cd}$, Co and V (ratio > 50). Similar ratios were found in Coleoidae (i.e. Sepia officinalis and Eledone cirrhosa) for $\mathrm{Cr}, \mathrm{Mn}, \mathrm{Fe}, \mathrm{Cd}$ and $\mathrm{Ag}$. On the contrary, $\mathrm{V}$ and $\mathrm{Co}$ are highly concentrated in the digestive gland of Nautilus whereas they are respectively poorly and moderately concentrated in Coleoidae. In the same way, $\mathrm{Ni}$ and $\mathrm{Zn}$ are moderately concentrated in the digestive gland of Nautilus but only poorly concentrated in S. officinalis and E. cirrhosa. High levels and storage of toxic metals in the digestive gland suggests efficient detoxification processes in this organ. Moreover, these high levels of toxic elements do not apparently disturb essential elements metabolism. Thus, it would be of particular interest to study detoxification processes in the digestive gland of nautilus.

\section{Conclusion}


Previous studies have demonstrated the ability of cephalopods to concentrate many trace elements. Data from nautilus species were particularly interesting on an evolutionary point of view. Indeed, as several elements are considered to be toxic for biota, marine animals would evolve to counteract their toxicity. It seems to be the case in cephalopods as they are able to growth and reproduce with very high metal concentrations. In their case, detoxification strategy involve storage mechanisms of these elements. This strategy appear to be efficient, and probably applied to minimise energetic cost, and is common among Nautilidae and Coleoidae cephalopods.

Enrichment of metals in New Caledonian waters appears to not be limited to coastal waters. Indeed, contamination by $\mathrm{Co}, \mathrm{Cr}$ and $\mathrm{Ni}$ is supported 1) by high levels in whole animals which are in the same order of magnitude than in bivalves and gastropods from contaminated areas 2 ) by relatively high levels in excretory organs and in hemolymph that indicate a high exposure to these metals 3 ) by higher ratios between concentrations in the muscle and in the digestive gland that show an enrichment in this organ. Further studies are needed to evaluate the scale of the contamination by these metals and possible effects on the ecosystems.

\section{Acknowledgements}

We thank Pascale Joannot, director of the Nouméa Aquarium, the ORSTOM Center of Nouméa and the crew of the O.V. Dawa for providing nautilus specimen. This work was supported financially by the "Conseil Régional Poitou-Charentes" and Rhodia (RhônePoulenc).

\section{References}


Amaratunga, T. The role of cephalopods in the marine ecosystem. In : IF Caddy (ed). Advances in assessment of world cephalopod resources. FAO Fish. Tech. Pap., 1983, 231, $379-415$.

Barghigiani, C., D'Ulivo, A., Zamboni, R., Lampugnani, L. Interaction between selenium and cadmium in Eledone cirrhosa of the Northern Tyrrhenian Sea. Mar. Pollut. Bull., 1993, 26(4), 212-216.

Bryan, G.W. The occurrence and seasonal variation of trace metals in the scallops Pecten maximus (L.) and Chlamys opercularis (L.). J. Mar. Biol. Ass. UK., 1973, 53, 145-166.

Bryan, G.W. (1976) Heavy metal contamination in the sea. In Marine pollution, ed. R. Jonhston, pp. 185-302. Academic Press.

Bryan, G.W., Hummerstone, L.G. Indicators of heavy metal contamination in the Looe estuary (Cornwall) with particular regard to silver and lead. J. Mar. Biol. Ass. UK., 1977, 57, 75-92.

Bryan, G.W., Hummerstone, L.G. Heavy metals in the burrowing bivalve Scrobicularia plana from contaminated and uncontaminated estuaries. J. Mar. Biol. Ass. UK., 1978, 58, 401-419.

Bustamante, P. (1998) Etude des processus de bioaccumulation et de détoxication d'éléments traces (métaux lourds et Terres Rares) chez les mollusques céphalopodes et bivalves pectinidés. Implication de leur biodisponibilité pour le transfert vers les prédateurs. Thesis, University of La Rochelle, 290 p 
Bustamante, P., Cherel, Y., Caurant, F., Miramand, P. Cadmium, copper and zinc in octopuses from Kerguelen Islands, Southern Indian Ocean. Polar Biol., 1998a, 19, 264-271.

Bustamante, P., Caurant, F., Fowler, S.W., Miramand, P. Cephalopods as a vector for the transfer of cadmium to top marine predators in the north-east Atlantic Ocean. Sci. Tot. Environ., 1998b, 220, 71-80.

Decleir, W., Vlaeminck, A., Geladi, P., Van Grieken, R. Determination of protein-bound copper and zinc in some organs of the cuttlefish Sepia officinalis L. Comp. Biochem. Physiol., 1978, 60B, 347-350.

Finger, J.M., Smith, J.D. Molecular association of $\mathrm{Cu}, \mathrm{Zn}, \mathrm{Cd}$ and ${ }^{210} \mathrm{Po}$ in the digestive gland of the squid Nototodarus gouldi. Mar. Biol., 1987, 95, 87-91.

Fox, D.L., Updegraff, D.M. Adenochrome a glandular pigment in the branchial hearts of the octopus. Archs. Biochem., 1943, 1, 339-356.

Froesch, D., Packard, A. Octopus chromatophores accumulate nickel. Experientia, 1979, 35, $828-829$.

Ghiretti-Magaldi, A., Giuditta, A., Ghiretti, F. Pathways of terminal respiration in marine invertebrates. I. The respiratory system in cephalopods. J. Cell. Comp. Physiol., 1958, 52, $389-429$. 
Guary, J.C., Higgo, J.J.W., Cherry, R.D., Heyraud, M. High concentrations of transuranic and natural radioactive elements in the branchial hearts of the cephalopods Octopus vulgaris. Mar. Ecol. Prog. Ser., 1981, 4, 123-126.

Guary, J.C., Fowler, S.C. Experimental studies on the biokinetics of plutonium and americium in the cephalopod Octopus vulgaris. Mar. Ecol. Prog. Ser., 1982, 7, 327-335.

Langston, W.J. Arsenic in U.K. estuarine sediments and its availability to benthic organisms. J. Mar. Biol. Ass. UK., 1980, 60, 869-881.

Martin, J.H., Flegal, A.R. High copper concentrations in squid livers in association with elevated levels of silver, cadmium, and zinc. Mar. Biol., 1975, 30, 51-55.

Miramand, P., Bentley, D. Concentration and distribution of heavy metals in tissues of two cephalopods, Eledone cirrhosa and Sepia officinalis, from the French coast of the English Channel. Mar. Biol., 1992, 114, 407-414.

Miramand, P., Guary, J.C. High concentrations of some heavy metals in tissues of the Mediterranean octopus. Bull. Environ. Contam. Toxicol., 1980, 24, 783-788.

Monniot, F., Martoja, R., Monniot, C. Cellular sites of iron and nickel accumulation in ascidians related to the naturally and anthropic enriched New Caledonian environment. Ann. Inst. Océanogr., 1994, 70(2), 205-216. 
Nakahara, M., Koyanagi, T., Ueda, T., Shimizu, C. Peculiar accumulation of cobalt-60 by the branchial hearts of Octopus. Bull. Jap. Soc. Scient. Fish., 1979, 45, 539.

Nardi, G., Steinberg, H. Isolation and distribution of adenochrome(s) in Octopus vulgaris. Comp. Biochem. Physiol., 1974, 48 B, 453-461.

Renzoni, A., Bacci, E., Falciai, L. Mercury concentration in the water, sediments and fauna of an area of the Tyrrhenian coast. Revue Int. Océanogr. Méd., 1973, 31-32, 17-45.

Rocca, E. Copper distribution in Octopus vulgaris Lam. hepatopancreas. Comp. Biochem. Physiol., 1969, 28, 67-82.

Rodhouse, P.G. Antarctic cephalopods - a living marine resource ? Ambio, 1989, 18(1), 56-59.

Rossi, A., Pellegrini, D., Belcari, P., Baghigiani, C. Mercury in Eledone cirrhosa from the Northern Tyrrhenian Sea: contents and relation with life cycle. Mar. Pollut. Bull., 1993, 26(12), 683-686.

Schipp, R., Hevert, F. Distribution of copper and iron in some central organs of Sepia officinalis (Cephalopoda). A comparative study by flamless atomic absorption and electron microscopy. Mar. Biol., 1978, 47, 391-399.

Smith, J.D. Radio-nuclides and heavy metals in Nototodarus gouldi. Mem. Nat. Museum Victoria, 1983, 44, 201-203. 
Smith, J.D., Plues, L., Heyraud, M., Cherry, R.D. Concentrations of the elements Ag, Al, Ca, $\mathrm{Cd}, \mathrm{Cu}, \mathrm{Fe}, \mathrm{Mg}, \mathrm{Pb}$ and $\mathrm{Zn}$, and the radionuclides ${ }^{210} \mathrm{~Pb}$ and ${ }^{210} \mathrm{Po}$ in the digestive gland of the squid Nototodarus gouldi. Mar. Environ. Res., 1984, 13, 55-68.

Ueda, T., Nakahara, M., Ishii, T., Suzuki, Y., Suzuki, H. Amounts of trace elements in marine cephalopods. J. Radiat. Res., 1979, 20, 338-342.

Yamada, H., Takayanagi, K., Tateishi. M., Tagata, H., Ikeda, K. Organotin compounds and polychlorinated biphenyls of livers in squid collected from coastal waters and open ocean. Environ. Pollut., 1997, 96(2), 217-226. 
Table 1. Comparison of trace elements concentrations ( $\mu \mathrm{g} / \mathrm{g}$ dry wt) of dogfish liver DOLT-2 (NRCC), Orchard Leaves SRM 1571 (NBS) and fish-flesh homogenates MAA2 (IAEA) determined in the present study with certified values.

\begin{tabular}{|c|c|c|c|c|c|c|c|c|c|c|c|c|}
\hline Standard & $\mathrm{Ag}$ & $\mathrm{Al}$ & As & $\mathrm{Cd}$ & Co & $\mathrm{Cr}$ & $\mathrm{Cu}$ & $\mathrm{Fe}$ & $\mathrm{Mn}$ & $\mathrm{Ni}$ & $\mathrm{V}$ & $\mathrm{Zn}$ \\
\hline \multicolumn{13}{|l|}{ DOLT-2 } \\
\hline Present study & $0.556 \pm 0.041$ & $26.9 \pm 3.5$ & $16.1 \pm 0.2$ & $20.4 \pm 0.27$ & $0.22 \pm 0.01$ & $0.39 \pm 0.09$ & $26.8 \pm 0.3$ & $1072 \pm 17$ & $6.26 \pm 0.11$ & $0.24 \pm 0.04$ & - & $86.3 \pm 1.2$ \\
\hline Certified values & $0.608 \pm 0.032$ & $25.2 \pm 2.4$ & $16.1 \pm 1.1$ & $20.8 \pm 0.05$ & $0.24 \pm 0.05$ & $0.37 \pm 0.08$ & $25.8 \pm 1.1$ & $1103 \pm 47$ & $6.88 \pm 0.56$ & $0.20 \pm 0.02$ & - & $85.8 \pm 2.5$ \\
\hline \multicolumn{13}{|l|}{ Orchard-Leaves } \\
\hline Present study & - & - & - & $0.13 \pm 0.02$ & $(0.15)$ & $(2.3)$ & $12 \pm 1$ & $290 \pm 15$ & $85 \pm 6$ & $1.5 \pm 0.1$ & $(0.5)$ & $25 \pm 1$ \\
\hline Certified values & - & - & - & $0.11 \pm 0.02$ & $(0.2)$ & (2.3) & $12 \pm 1$ & $300 \pm 20$ & $91 \pm 4$ & $1.3 \pm 0.2$ & $(0.6)$ & $25 \pm 3$ \\
\hline \multicolumn{13}{|l|}{ MA-A-2 } \\
\hline Present study & $0.09 \pm 0.03$ & - & - & $0.063 \pm 0.002$ & $0.06 \pm 0.01$ & $1.1 \pm 0.1$ & $3.7 \pm 0.2$ & $51 \pm 2$ & $0.69 \pm 0.09$ & $1.2 \pm 0.1$ & - & $32 \pm 3$ \\
\hline Certified values & $0.10 \pm 0.01$ & - & - & $0.066 \pm 0.004$ & $0.08 \pm 0.01$ & $1.3 \pm 0.1$ & $4.0 \pm 0.1$ & $54 \pm 1$ & $0.81 \pm 0.04$ & $1.1 \pm 0.2$ & - & $33 \pm 1$ \\
\hline
\end{tabular}



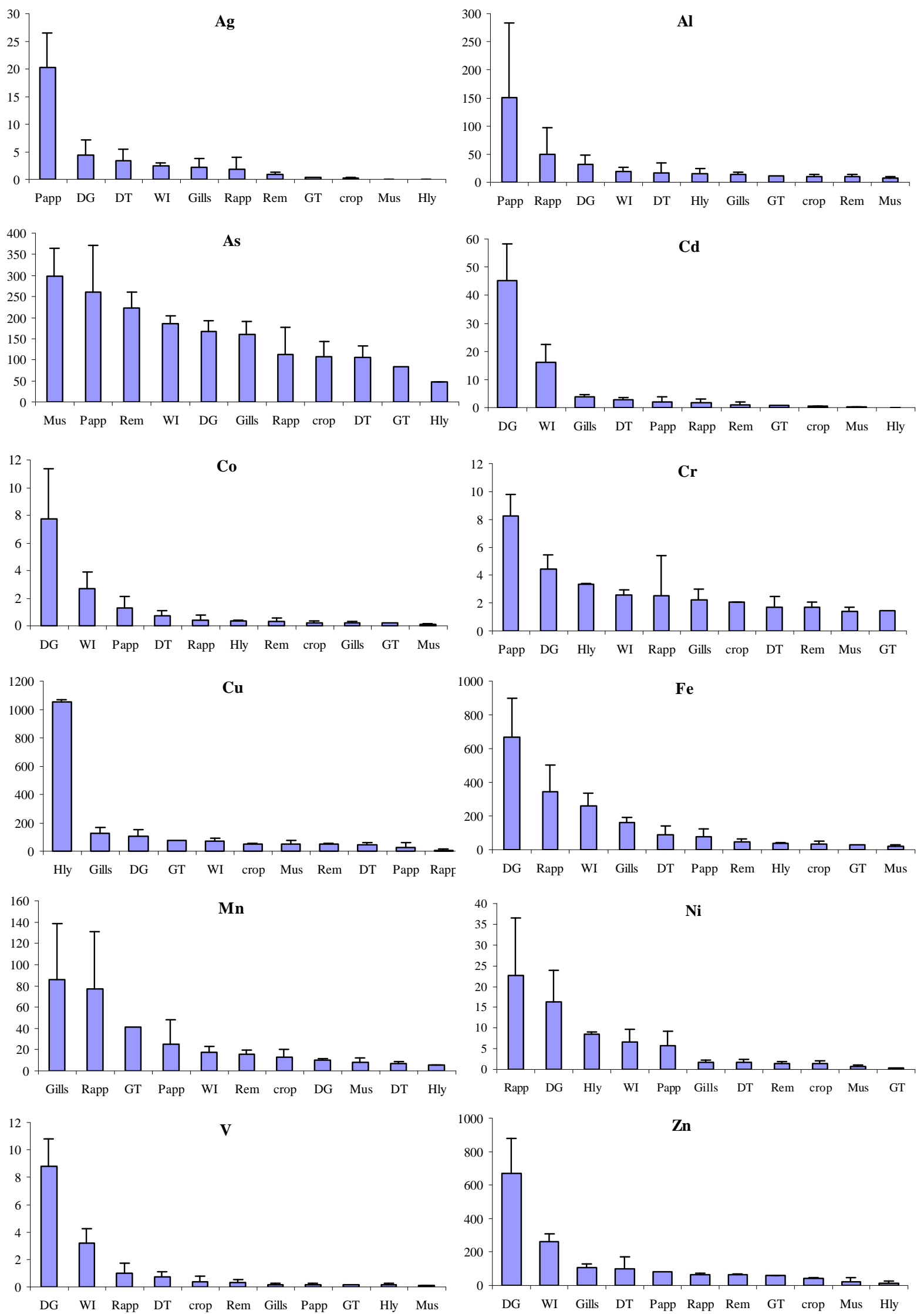

Figure 1. Trace elements concentrations ( $\mu \mathrm{g} / \mathrm{g}$ dry wt) in the tissues of Nautilus macromphalus from New Caledonia. Scale bars represent 1 standard deviation. DG: digestive gland; DT: digestive tract; GT: genital tract; Hly: hemolymph; Mus: muscle; Papp: pericardial appendages; Rapp: renal appendages; Rem: remainders; WI: whole individual. 

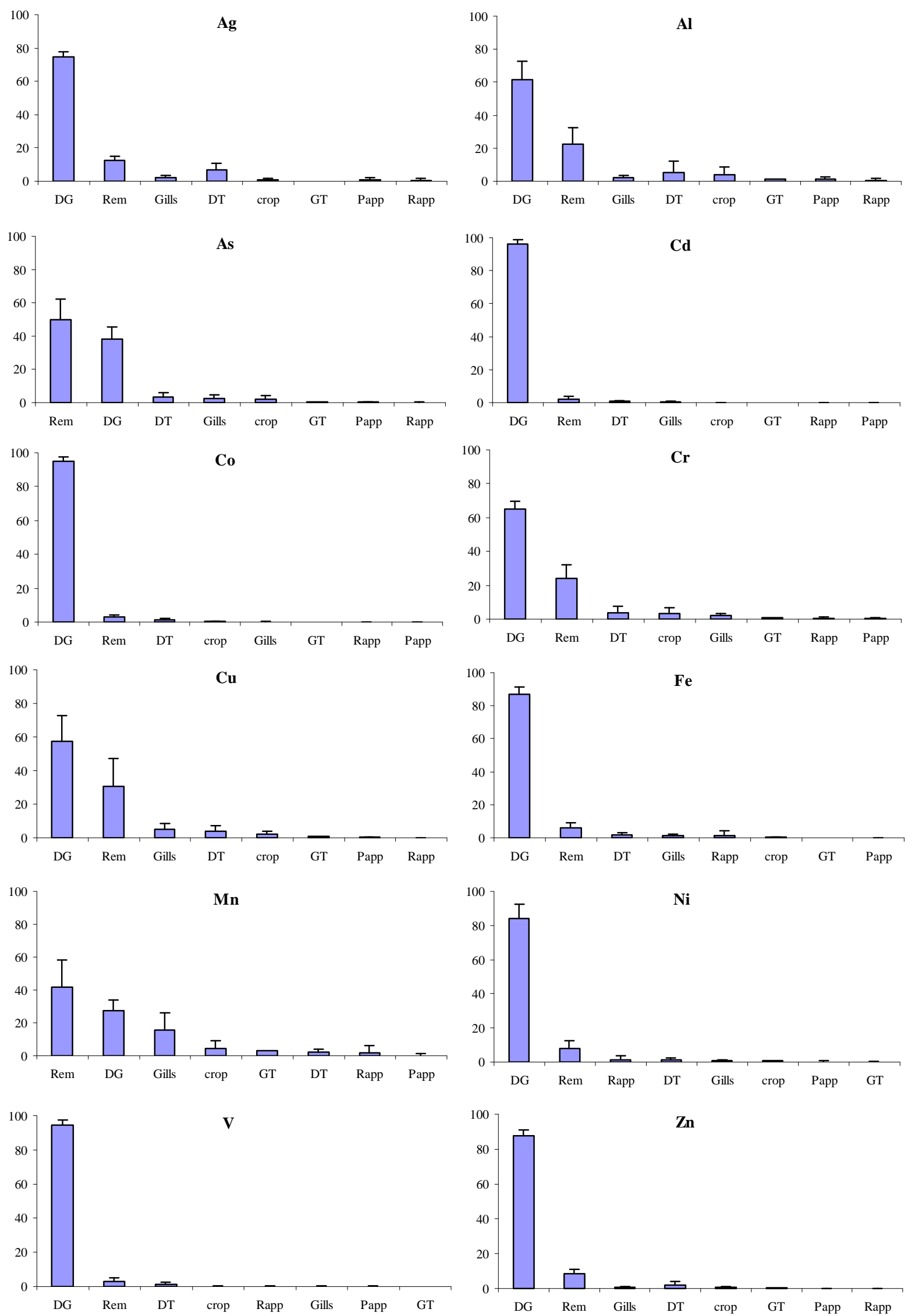

Figure 2. Percentages distribution of trace elements in the tissues of Nautilus macromphalus from New Caledonia. Scale bars represent 1 standard deviation. DG: digestive gland; DT: digestive tract; GT: genital tract; Hly: hemolymph; Papp: pericardial appendages; Rapp: renal appendages; Rem: remainders; WI: whole individual. 
Table 2. Trace element concentrations ( $\mu \mathrm{g} / \mathrm{g}$ dry wt) in molluscs from this study and from the literature. Values are mean $\pm 1 \mathrm{SD}$, except from species marked * which are minimum and maximum values; * also indicates species from contaminated areas.

\begin{tabular}{|c|c|c|c|c|c|c|c|c|c|c|c|c|c|}
\hline $\begin{array}{l}\text { Class } \\
\text { Species }\end{array}$ & $\mathrm{Ag}$ & $\mathrm{Al}$ & As & $\mathrm{Cd}$ & Co & $\mathrm{Cr}$ & $\mathrm{Cu}$ & $\mathrm{Fe}$ & $\mathrm{Mn}$ & $\mathrm{Ni}$ & $\mathrm{V}$ & $\mathrm{Zn}$ & Authors \\
\hline \multicolumn{14}{|l|}{ Cephalopods } \\
\hline Eledone cirrhosa & $0.76 \pm 0.48$ & - & - & $5.36 \pm 1.09$ & $0.45 \pm 0.09$ & $0.6 \pm 0.1$ & $122 \pm 11$ & $81 \pm 12$ & $1.9 \pm 0.5$ & $0.8 \pm 0.1$ & $1.0 \pm 0.2$ & $234 \pm 20$ & Miramand \& Bentley (1992) \\
\hline Nautilus macromphalus & $2.4 \pm 0.6$ & $19 \pm 7$ & $186 \pm 18$ & $16.0 \pm 6.5$ & $2.7 \pm 1.2$ & $2.6 \pm 0.3$ & $73 \pm 20$ & $258 \pm 79$ & $17 \pm 6$ & $6.7 \pm 3.0$ & $3.2 \pm 1.1$ & $260 \pm 49$ & Present study \\
\hline Octopus vulgaris & - & - & - & $1.2 \pm 0.1$ & - & - & $260 \pm 70$ & $140 \pm 10$ & $5 \pm 0.5$ & - & $0.7 \pm 0.1$ & $150 \pm 50$ & Miramand \& Guary (1980) \\
\hline Sepia officinalis & $0.66 \pm 0.01$ & - & - & $1.34 \pm 0.03$ & $0.39 \pm 0.07$ & $1.0 \pm 0.1$ & $59 \pm 1$ & $43 \pm 4$ & $1.6 \pm 0.1$ & $0.4 \pm 0.1$ & $0.7 \pm 0.2$ & $134 \pm 6$ & Miramand \& Bentley (1992) \\
\hline \multicolumn{14}{|l|}{ Bivalves } \\
\hline Cerastoderma edule * & $0.11-6.5$ & - & - & $0.48-1.04$ & $1.28-2.93$ & $1.34-2.46$ & $5.2-27.2$ & 406-991 & $6.2-44.6$ & $34-62$ & - & $46-66$ & Bryan \& Hummerstone (1977) \\
\hline Macoma balthica * & 19-128 & - & - & $0.85-0.21$ & $3.7-6.8$ & $1.89-3.30$ & $96-615$ & $502-1540$ & $19-24$ & $6.9-7.9$ & - & $510-1160$ & " \\
\hline Mytilus edulis * & $0.10-0.55$ & - & - & $0.84-2.64$ & $0.02-1.07$ & $0.94-2.74$ & $3.9-13.6$ & $152-401$ & $5.2-35.4$ & 0.9-3.5 & - & $57-199$ & " \\
\hline Pecten maximus & 2.7 & 55 & - & 32.5 & $0.25 \pm 0.09$ & 1.3 & $8.9 \pm 4.5$ & $196 \pm 83$ & $107 \pm 60$ & $0.73 \pm 0.25$ & - & $273 \pm 95$ & Bryan (1973) \\
\hline Scrobicularia plana $*$ & $0.23-1.2$ & - & - & $0.29-14.9$ & $4.3-66$ & $1.2-2.2$ & $25-86$ & $699-1240$ & 19-87 & $3.4-11.9$ & - & $353-2940$ & Bryan \& Hummerstone (1978) \\
\hline S. plana $*$ & - & - & $5-190$ & - & - & - & - & - & - & - & - & - & Langston (1980) \\
\hline \multicolumn{14}{|l|}{ Gastropods } \\
\hline Littorina littorea $*$ & $3.2-73$ & - & - & $0.49-2.56$ & $0.79-3.04$ & $0.13-0.98$ & $62-194$ & $272-784$ & $18-133$ & $2.2-4.1$ & - & $45-284$ & Bryan \& Hummerstone (1977) \\
\hline Patella vulgata $*$ & $1.5-6.0$ & - & - & $3.3-21.5$ & $0.24-1.56$ & $0.48-2.62$ & $10-27$ & $891-2330$ & $5.4-36.0$ & $1.7-3.7$ & - & $83-224$ & \\
\hline
\end{tabular}


Table 3. Trace element concentrations $(\mu \mathrm{g} / \mathrm{g}$ dry wt) determined in the digestive gland of cephalopods from this study and from the literature.

\begin{tabular}{|c|c|c|c|c|c|c|c|c|c|c|c|c|c|}
\hline Species & $\mathrm{Ag}$ & $\mathrm{Al}$ & As & $\mathrm{Cd}$ & Co & $\mathrm{Cr}$ & $\mathrm{Cu}$ & $\mathrm{Fe}$ & $\mathrm{Mn}$ & $\mathrm{Ni}$ & V & $\mathrm{Zn}$ & Authors \\
\hline Nautilus macromphalus & $4.45 \pm 2.68$ & $32.1 \pm 16.3$ & $166 \pm 26$ & $45.1 \pm 13.2$ & $7.8 \pm 3.6$ & $4.4 \pm 1.1$ & $106 \pm 46$ & $666 \pm 231$ & $10.1 \pm 1.7$ & $16.3 \pm 7.8$ & $8.8 \pm 2.0$ & $672 \pm 208$ & Present study \\
\hline Sepia officinalis & $6.15 \pm 1.75$ & & & $12.67 \pm 0.35$ & $3.27 \pm 0.6$ & $1.1 \pm 0.1$ & $315 \pm 3$ & $244 \pm 28$ & $3.3 \pm 0.1$ & $1.3 \pm 0.4$ & $5.0 \pm 1.3$ & $571 \pm 47$ & Miramand \& Bentley (1992) \\
\hline Loligo opalescens & $251.1 \pm 12.6$ & & & $85.0 \pm 51.6$ & & & $5350 \pm 3210$ & $111 \pm 73$ & & & & $247 \pm 131$ & Martin \& Flegal (1975) \\
\hline L. opalescens & $45.9 \pm 19.0$ & & & $121.5 \pm 57.9$ & & & $8370 \pm 3130$ & $87 \pm 49$ & & & & $449 \pm 201$ & " \\
\hline Nototodarus gouldi & & & & $33 \pm 30$ & & & $363 \pm 238$ & & & & & $830 \pm 355$ & Finger \& Smith (1987) \\
\hline N. gouldi & $3.3 \pm 1.4$ & $7.7 \pm 4.0$ & & $50 \pm 25$ & & & $246 \pm 298$ & $745 \pm 440$ & $4.2 \pm 1.1$ & & & $696 \pm 295$ & Smith et al. (1984) \\
\hline Ommastrephes bartrami & $12.1 \pm 8.6$ & & & $287 \pm 202$ & & & $195 \pm 212$ & $399 \pm 204$ & & & & $163 \pm 55$ & Martin \& Flegal (1975) \\
\hline Stenoteuthis oualaniensis & $24.1 \pm 10.9$ & & & $782 \pm 255$ & & & $1720 \pm 151$ & $319 \pm 67$ & & & & $513 \pm 288$ & " \\
\hline Eledone cirrhosa & $3.20 \pm 1.74$ & & & $24.00 \pm 1.75$ & $2.06 \pm 0.0$ & $0.8 \pm 0.1$ & $456 \pm 11$ & $287 \pm 13$ & $4.2 \pm 1.6$ & $2.5 \pm 0.1$ & $3.3 \pm 0.5$ & $646 \pm 86$ & Miramand \& Bentley (1992) \\
\hline Benthoctopus thielei & & & & 215 & & & 42 & & & & & 416 & Bustamante et al. (1998a) \\
\hline Graneledone sp. & & & & 369 & & & 1092 & & & & & 102 & Bustamante et al. (1998a) \\
\hline Octopus vulgaris & & & & & & & 2550 & 1920 & & & & & Ghiretti-Magaldi et al. (1958) \\
\hline O. vulgaris & & & & $50 \pm 10$ & & & $2500 \pm 700$ & $700 \pm 130$ & $7.0 \pm 0.5$ & & $4.5 \pm 1.0$ & $1450 \pm 400$ & Miramand \& Guary (1980) \\
\hline
\end{tabular}

